\title{
Potential and economics of Ragi (Eleusine coracana L. Gaertn.) cultivation under changing weather conditions of Ranchi, Jharkhand
}

\author{
Nishar Akhtar ${ }^{1}$, Anwesha Dey ${ }^{2}$, Gufran Ahmad ${ }^{3}$, \\ Firoz Ahmad ${ }^{4}$ and Md. Mahtab Rashid ${ }^{2 *}$
}

\author{
${ }^{I}$ Department of Plant Pathology, Birsa Agricultural University, Ranchi, India \\ ${ }^{2}$ Institute of Agricultural Sciences, Banaras Hindu University, Varanasi, India \\ ${ }^{3}$ K.V.K., Mahoba, Banda University of Agriculture and Technology, Banda, India \\ ${ }^{4}$ Birsa Agricultural University, Ranchi, India
}

*Corresponding author

\section{Keywords}

Weather change,

Rainfall,

Temperature,

Potential

evapotranspiration,

Substitute crop,

Ragi, Production

potential, $\mathrm{B}: \mathrm{C}$ ratio

Article Info

Accepted:

05 January 2020

Available Online:

10 February 2020

\section{A B S T R A C T}

Jharkhand agricultural system is mainly dependent upon the weather conditions and the monsoon rainfall during the Kharif season. The state agricultural system is lagging behind because of low productivity, monocropping, erratic rainfall, and frequent dry spells. In addition to that, there is also a change in the weather pattern which will have a more significant negative impact on production and productivity of crops in the state, if the farming community continues with their indigenous practices. Ragi is a drought-tolerant and highly nutritional crop which has an economic value and productivity in the range of major cereals. The present study was conducted to find out the change in rainfall and temperature pattern of Ranchi as per the data available from 1950. Ragi variety, Birsa Madua-1, was tested for its productivity and economics in four villages of Ranchi under the weather conditions of Kharif season of 2018. It was concluded that there is a shift of rainfall in the district and rainfall period of Kharif crops is decreasing. There is also an increase in temperature and potential evapotranspiration. Ragi showed adaptability and stability even under the changing conditions with a B:C ratio of 2.28. Thus, it can be concluded that farmers should be made aware of the changing weather pattern and encourage them to cultivate ragi in order to combat the changing scenario. 


\section{Introduction}

Weather condition is a key player in the agricultural system where it defines the type of crop to be grown under a particular set. Among the weather parameters, rainfall and temperature are the two most important ones which have a significant effect on the growth and production of a crop plant. Rainfall is a physical phenomenon of water transportation from the atmosphere back to the earth's surface (Shree and Kumar, 2018). Temperature, on the other hand, is the degree of hotness or coldness that is observed over an area over an interval of time. It depends on various processes such as radiation of the sun, the intensity of sunlight, cloudiness, suspended particulate material in air, etc. The knowledge of accurate trend of rainfall and temperature of an area can have a very good impact on the agriculture as we would be able to conform our farm practices according to it, in order to get maximum and sustainable production. In recent time, the world is observing a drastic change and variation in both the pattern of rainfall and temperature range which has resulted in many catastrophic crop failures.

Jharkhand is a relatively new state of India whose agricultural activities just like the rest of the country is dependent on rainfall brought by the south-west monsoon. It contributes to $85 \%$ of the rainfall in the state and success or failure of crops is directly proportional to the outset, advancement, and retraction of monsoon. The study of rainfall and temperature pattern from the recorded meteorological data have always been helpful in predicting the near future weather conditions. This, in turn, has aided in manipulating the agricultural practices in accordance to get optimum production. Thus, it is very crucial to find alternative crops which can be switched with the previously grown crops keeping in mind the changing weather conditions. There is a transformation in the agricultural system of Jharkhand where high-value crops have been taken place of low-value crops (Singh and Prakash, 2017). The area under cultivation for previously grown crops such as rice and minor millets is declining and area of wheat, vegetables, and other horticultural crops is increasing. This change is feasible only with increased application of irrigation and chemical fertilizers in the agricultural fields along with the use of high-yielding and hybrid varieties. Although, this change has brought economic development and increased supply of agricultural produces, over-use of irrigation, chemical fertilizers, and soil exhaustive crop varieties are degrading the cropland of the state. So, there is a need to find out a crop which requires minimum irrigation and fertilizers, non-exhaustive to the soil, can sustain the changing weather conditions, and in the meantime does not slow-down the economic development as well as provide a similar amount of agricultural supply.

Eleusine coracana (L.) Gaertn., familiarly known as ragi or finger millet or madua is a very important minor-millet which is substantially grown in India and Africa as a staple food for a certain population (Devi et al., 2014). It belongs to the Poaceae family and is an inhabitant of Ugandan and Ethiopian highlands (Adugna et al., 2011). It is considered to be a model nutraceutical crop owing to its health benefits to humans (Gupta et al., 2017). Many epidemiological researches have shown that routine consumption of ragi whole grain and its derived products lower the risk of type II diabetes, cardiovascular diseases, gastrointestinal cancers, and a number of other disorders (Mckeown et al., 2002; Devi et al., 2014). The whole ragi grain products contain ample amount of minerals, dietary fibres, vitamins, and phenolics which helps to combat hyperglycaemia and oxidative stress 
(Antony et al., 1996; Antony, 1998). The separated seed coat from grains of malting and milling ragi can be used as a constituent of special food supplement and as a whole, the nutrient content of ragi is comparable to mainstream cereals like rice, maize, wheat, barley, and bajra (Devi et al., 2014).

Ragi is consumed in Jharkhand in different food preparations such as porridge, chapati, cake, cookies, kurha, and sweetmeat. In addition to these, boiled and malted germinated grains are used as a food supplement to infants and pregnant women as it does not form acids and is easy to digest. Ragi is considered to be one of the most nutritious, highly digestible, and least allergic food grain (Singh and Raghuvanshi, 2012). Apart from this, ragi has the ability to grow on least fertile soils without the application of chemical fertilizers, thus making itself suitable for cultivation in arid and semi-arid areas (Gull et al., 2014). It is also considered as a drought-tolerant crop due to higher water use efficiency with enhanced fixation of $\mathrm{CO}_{2}$ and minimal leaf area. Moreover, it is also utilizes soil nitrogen very efficiently and is resistant to various storage pests (Mgonja et al., 2007; Gupta et al., 2014, 2017). There is also increased recognition of ragi nowadays as a better food crop among consumers which presents an opportunity for the farming community to derive economic benefit from ragi production. All these characteristics of ragi make it a potential candidate as a substitution crop in the changing weather conditions of Jharkhand without hampering the economic returns and nutritive component.

The present study was thus conducted to study the pattern of rainfall and temperature pattern of Ranchi district of Jharkhand over a period of time, physicochemical properties of soil in that district, and production potential of ragi in that area under present weather conditions.

\section{Materials and Methods}

For the present study, Ranchi district of Jharkhand was selected and the monthly data of rainfall, minimum temperature, maximum temperature, diurnal temperature range, and potential evapotranspiration was collected from India Water Portal website (https://www.indiawaterportal.org/met_data/) and Metrological Observatory of ATMA, Ranchi. Four villages were selected for the field survey namely Husir $\left(23.4602^{\circ} \mathrm{N}\right.$ and $\left.85.3343^{\circ} \mathrm{E}\right)$, Sukurhutu $\left(23.4454855^{\circ} \mathrm{N}\right.$ and $\left.85.2903^{\circ} \mathrm{E}\right), \quad$ Bukru $\left(23.4809^{\circ} \mathrm{N}\right.$ and $\left.85.3080^{\circ} \mathrm{E}\right)$, and Patratoli $\left(23.4350^{\circ} \mathrm{N}\right.$ and $85.3337^{\circ} \mathrm{E}$ ) that comes in area of Kanke in Ranchi district.

The soil samples were taken at a depth of 0$30 \mathrm{~cm}$ from the experimental sites randomly and were subjected to the analysis of their physicochemical properties using standard procedures. Birsa Madua-1 variety was selected for the production potential test of ragi crop which is released from Birsa Agricultural University, Ranchi, Jharkhand. The crop variety was grown during Kharif season of 2018 in the experimental sites of selected villages and the obtained grains from each plot was sundried, cleaned, and weighed for data collection and further analysis.

\section{Results and Discussion}

\section{Rainfall and temperature pattern from 1950 to 2002}

From the data available on India Water Portal website, we can see that the rainfall (in $\mathrm{mm}$ ) is mainly higher from the month of June to October with its highest intensities in July and August (Figure 1a and 1b). In the more current years, we can see that the rainfall is comparatively lower in the month of June and July while there is an increase during September and October. The amount of rainfall received during the Kharif season of 
2018 is provided in Table 1. The monthly maximum and minimum temperature of Ranchi from 1950 to 2002 is depicted in Figure 2. From the pattern, it is seen that the maximum temperature $\left({ }^{\circ} \mathrm{C}\right)$ is highest in the month of May followed by April, June, and March.

The minimum temperature $\left({ }^{\circ} \mathrm{C}\right)$ was also observed highest in the month of May followed by June. However, it was seen that the minimum temperatures were higher in the month of July, August, September, and April. The monthly diurnal temperature range $\left({ }^{\circ} \mathrm{C}\right)$ is shown in Figure 3. The figure shows that the temperature difference $\left({ }^{\circ} \mathrm{C}\right)$ between the maximum and minimum temperatures is more in the months of March, April and May; while it is least in the months of August, July, September, and October. The potential evapotranspiration (PET) (mm day $\left.{ }^{-1}\right)$ of Ranchi is depicted in Figure 4. From the figure, we can clearly see that the highest PET is in the month of May followed by April, June, and March subsequently. The comparatively lower PET can be seen in the months of August and September.

\section{Physicochemical properties of soil}

The soil samples showed a clay-loam texture, were acidic in reaction, had low organic carbon, high availability of phosphorous, and medium availability of potassium. The detailed properties of the soil are given in table 2 . The only deficient mineral in the soil was organic carbon otherwise, all the essential nutrients were present in sufficient quantities.

Table.1 Rainfall received in Ranchi during the Kharif season of 2018

\begin{tabular}{|c|c|c|c|c|}
\hline \multirow{2}{*}{$\begin{array}{c}\text { Rainfall summary } \\
\text { for month }\end{array}$} & \multirow{2}{*}{$\begin{array}{l}\text { Actual } \\
(\mathbf{m m})\end{array}$} & \multirow{2}{*}{$\begin{array}{l}\text { Normal } \\
(\mathbf{m m})\end{array}$} & \multirow{2}{*}{$\begin{array}{c}\text { Deficiency } \\
\text { (Actual minus } \\
\text { Normal) (mm) }\end{array}$} & \multirow{2}{*}{$\begin{array}{c}\text { Deviation }(\%) \\
\frac{(\text { Actual }- \text { Normal })}{\text { Normal }} \times 100\end{array}$} \\
\hline & & & & \\
\hline June & 50.3 & 165.7 & $-115.4^{*}$ & $-69.64 *$ \\
\hline July & 170.7 & 323.7 & $-153 *$ & $-47.26^{*}$ \\
\hline August & 126.8 & 322.9 & $-152.2^{*}$ & $-46.13 *$ \\
\hline September & 117.2 & 214.3 & $-97.1 *$ & $-45.31 *$ \\
\hline October & 18.6 & 64.6 & $-46^{*}$ & $-71.20 *$ \\
\hline Total & 483.6 & 1091.2 & $-607.6^{*}$ & $-55.68 *$ \\
\hline $\begin{array}{l}\text { Details of dry spells } \\
\text { experienced (if any) }\end{array}$ & \multicolumn{4}{|c|}{$\begin{array}{l}\text { 1)From:03 Jun to } 22 \text { June; number of days: } 20 \\
\text { 2)From: 06Jul to } 16 \mathrm{July} \text {; number of days: } 11 \\
\text { 3)From: } 07 \text { Aug to } 12 \mathrm{Aug} \text {; number of days: } 06 \\
\text { 4)From: } 11 \mathrm{Sept} \text { to } 20 \mathrm{Sept} \text {; number of days: } 10 \\
\text { 5)From: 01Oct to } 11 \mathrm{Oct} \text {; number of days: } 11 \\
\text { 6)From: } 13 \mathrm{Oct} \text { to } 31 \mathrm{Oct} \text {; number of days: } 19\end{array}$} \\
\hline $\begin{array}{c}\text { Delay in the onset of } \\
\text { monsoon }\end{array}$ & \multicolumn{4}{|c|}{ Delay by 20 Days } \\
\hline \multicolumn{5}{|c|}{ * - sign shows a decrease from normal } \\
\hline
\end{tabular}


Table.2 Physicochemical properties of the soil from the demonstrated fields

\begin{tabular}{|c|c|c|c|c|}
\hline S.No & Parameter & Value & Unit & Result \\
\hline \multicolumn{5}{|c|}{ I. Physical characteristics } \\
\hline 1. & Coarse sand & $40-42$ & $\%$ & \multirow{4}{*}{$\begin{array}{c}\text { Sandy } \\
\text { clay loam }\end{array}$} \\
\hline 2. & Fine sand & $28-30$ & $\%$ & \\
\hline 3. & Silt & 6-7 & $\%$ & \\
\hline 4. & Clay & $25-27$ & $\%$ & \\
\hline \multicolumn{5}{|c|}{ II. Chemical characteristics } \\
\hline 1. & $\mathrm{pH}$ & 4.5- 6 & & Acidic \\
\hline 2. & $\mathrm{EC}$ & $0.05-0.06$ & $\mathrm{dS} \mathrm{m}{ }^{-1}$ & Sufficient \\
\hline 3. & Organic Carbon & $0.40-0.43$ & $\%$ & Deficient \\
\hline 4. & Available N & $380-385$ & $\mathrm{~kg} \mathrm{ha}^{-1}$ & Sufficient \\
\hline 5. & Available P & $18-21$ & $\mathrm{~kg} \mathrm{ha}^{-1}$ & Sufficient \\
\hline 6. & Available K & $140-145$ & $\mathrm{~kg} \mathrm{ha}^{-1}$ & Sufficient \\
\hline 7. & Available S & $30-32$ & ppm & Excess \\
\hline 8. & Available $\mathrm{Zn}$ & $2.5-2.7$ & ppm & Sufficient \\
\hline 9. & Available B & $1.2-1.3$ & ppm & Sufficient \\
\hline 10. & Available Fe & $15-16$ & ppm & Sufficient \\
\hline 11. & Available Mn & $30-32$ & ppm & Sufficient \\
\hline 12. & Available $\mathrm{Cu}$ & $2.35-2.45$ & ppm & Sufficient \\
\hline
\end{tabular}

Table.3 Performance and Economics of Birsa Madua-1 (drought tolerant ragi variety) during Kharif, 2018

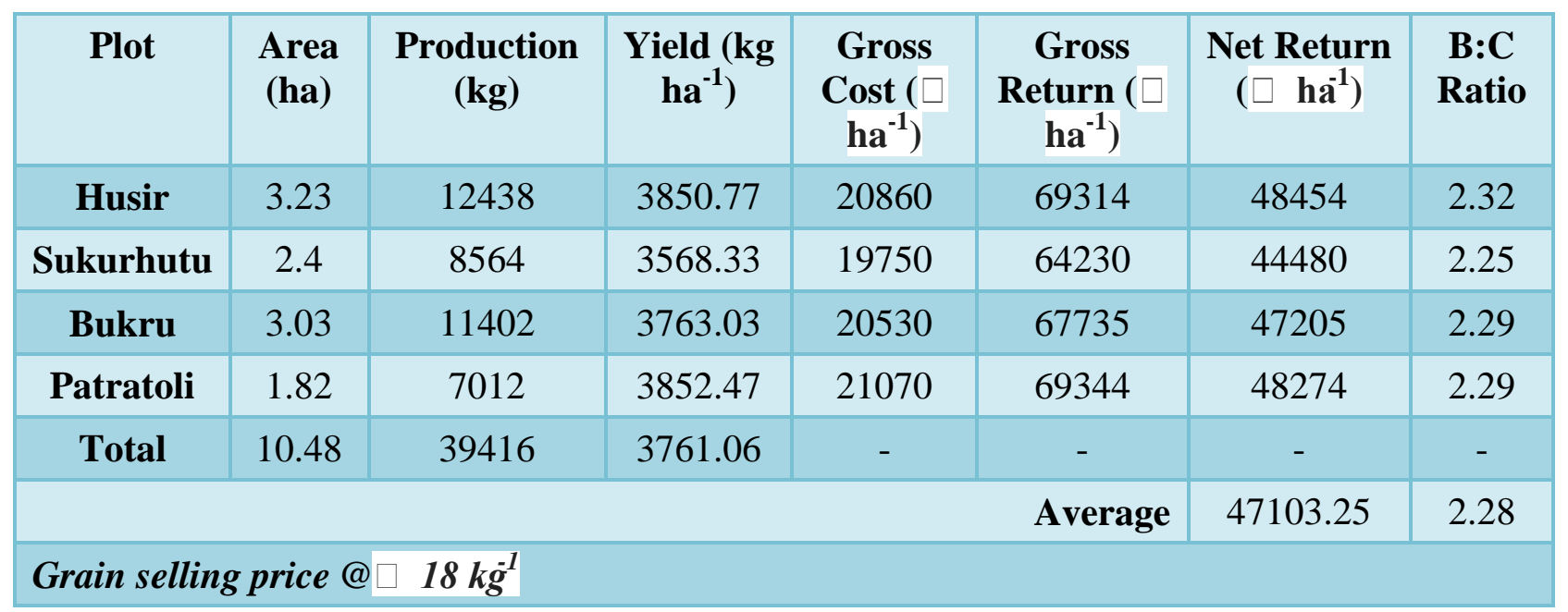


Figure.1a Monthly rainfall (in $\mathrm{mm}$ ) received in Ranchi from 1950 to 2002. (Date Source: India Water Portal)

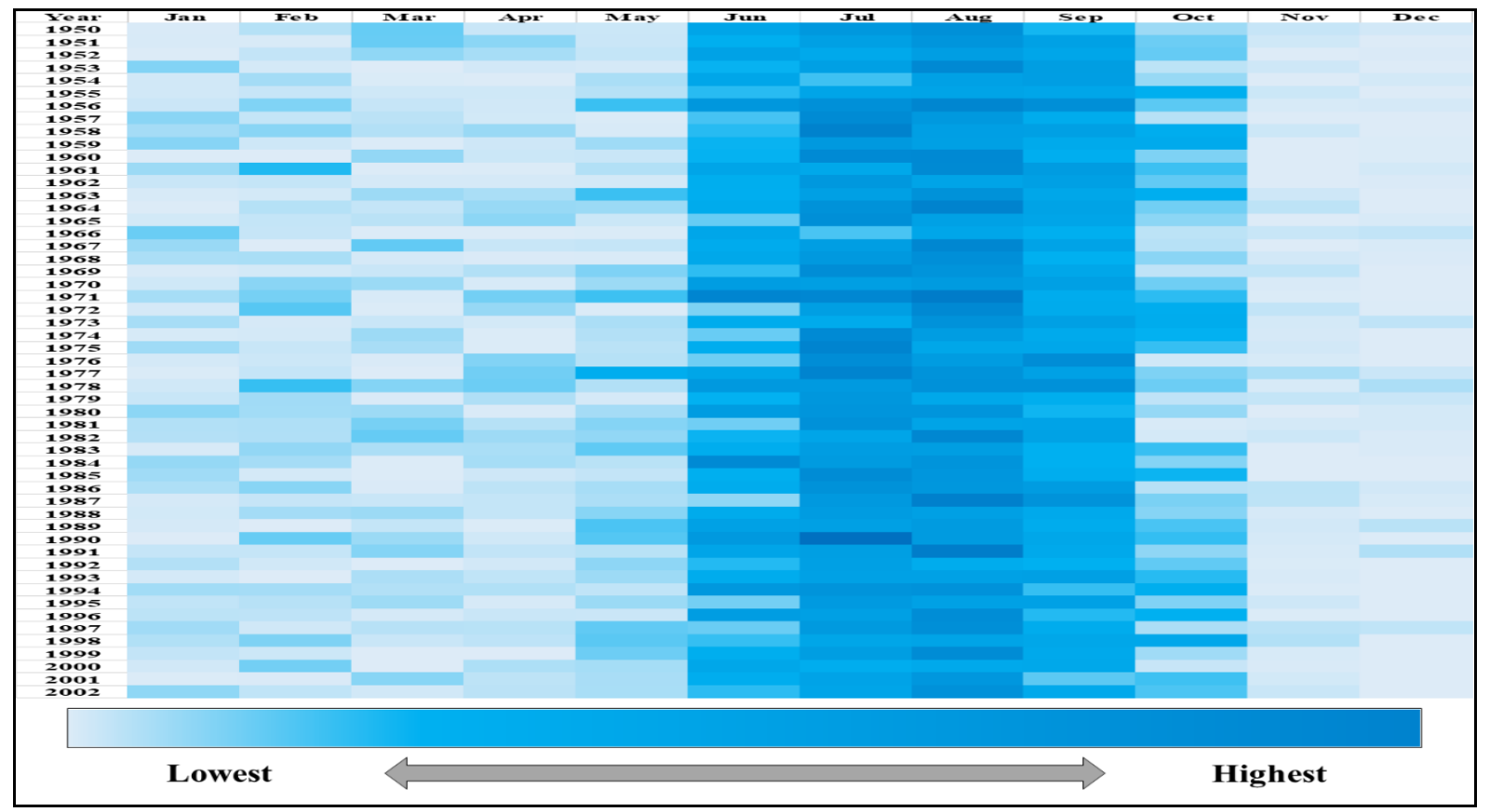

Figure.1b Rainfall (in mm) received in Ranchi from 1950 to 2002 in alternate months of the year. (Data Source: India Water Portal)

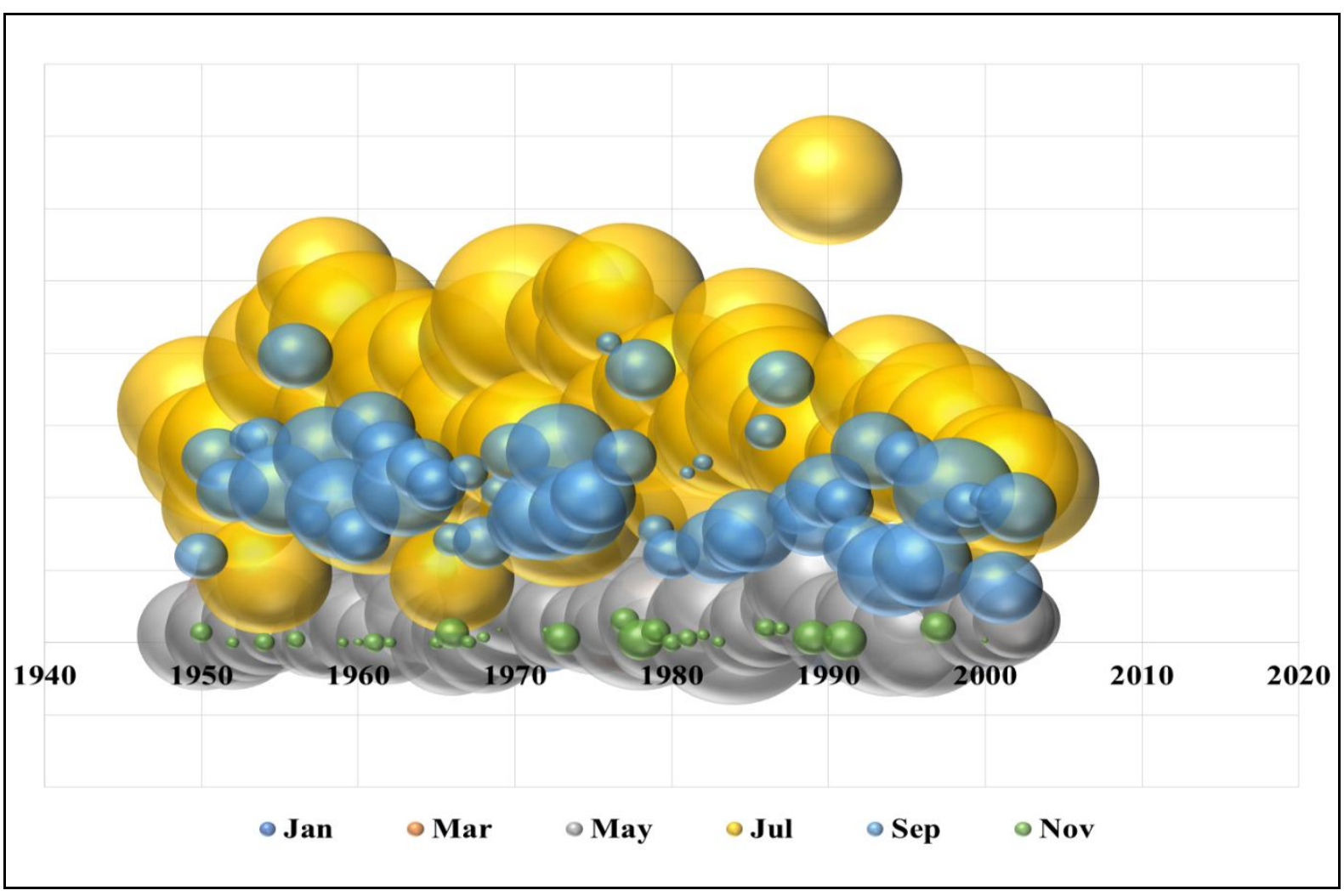


Figure.2 Monthly maximum (left) and minimum (right) temperatures recorded in Ranchi from 1950 to 2002 (Data Source: India Water Portal)
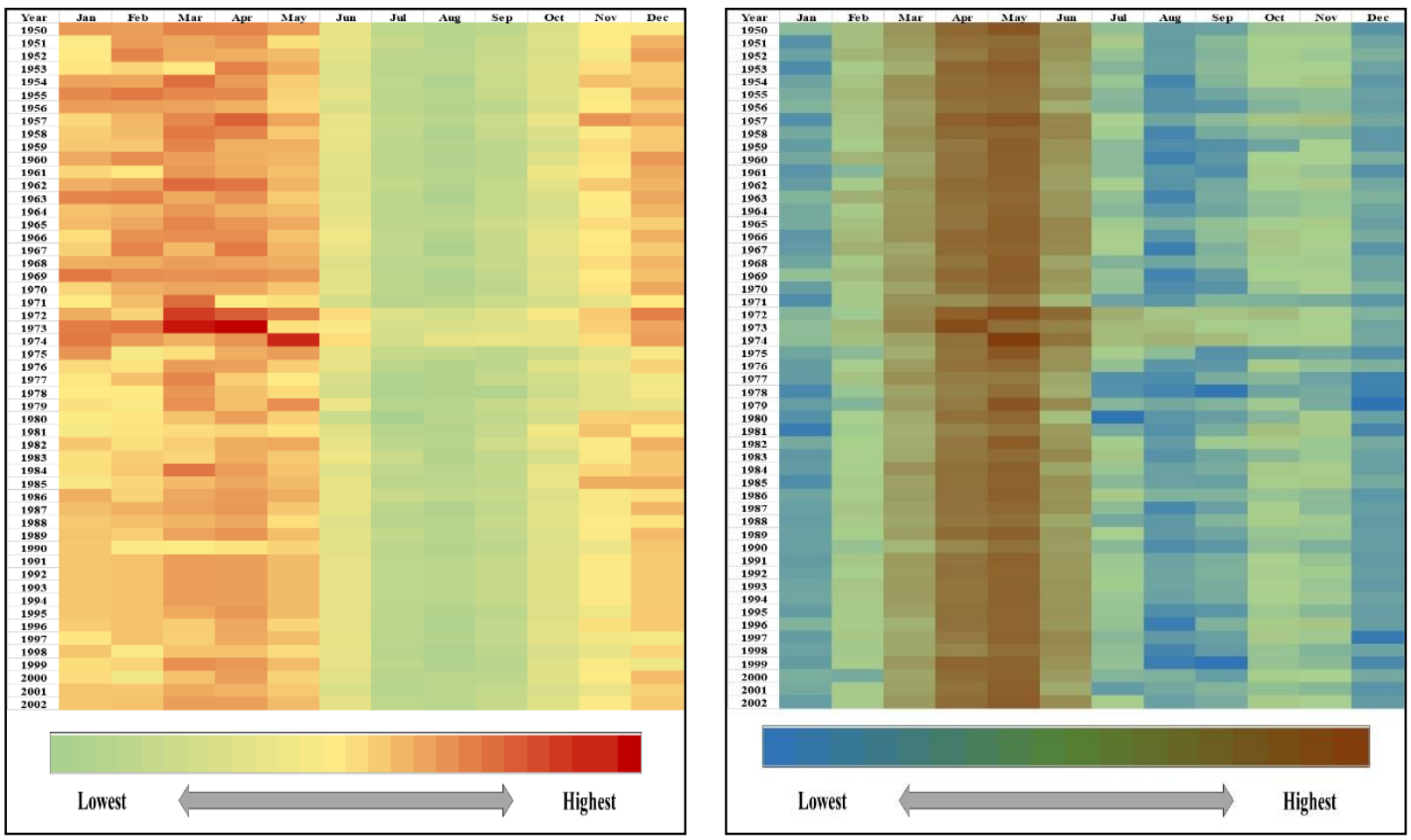

Figure.3 (Left) and 4 (Right): Monthly diurnal temperature range $\left({ }^{\circ} \mathrm{C}\right)$ and potential evapotranspiration $\left(\mathrm{mm} \mathrm{day}^{-1}\right.$ ) of Ranchi from 1950 to 2002. (Data Source: India Water Portal)
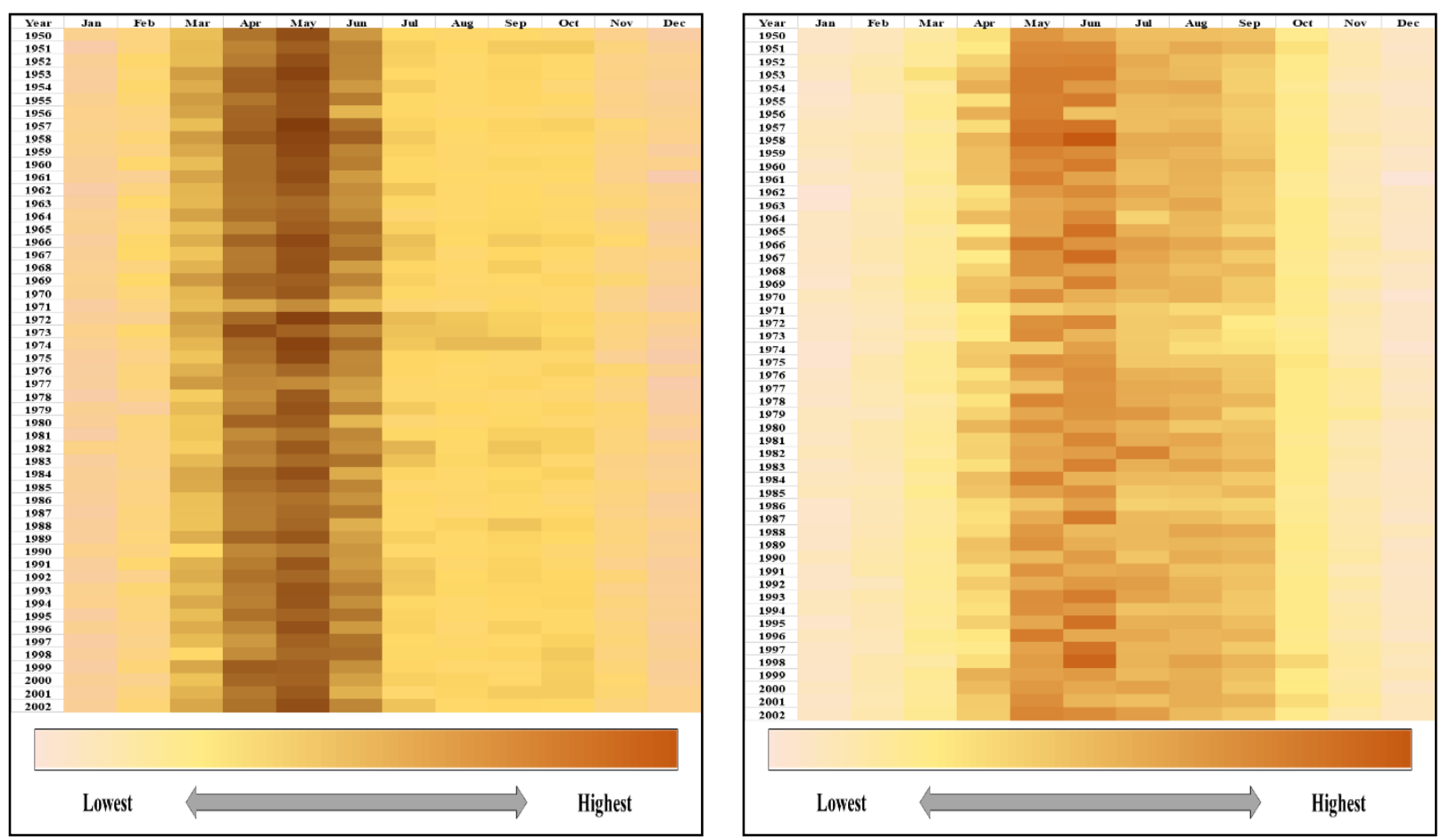
Figure 5: Birsa Madua-1 in different fields of four villages
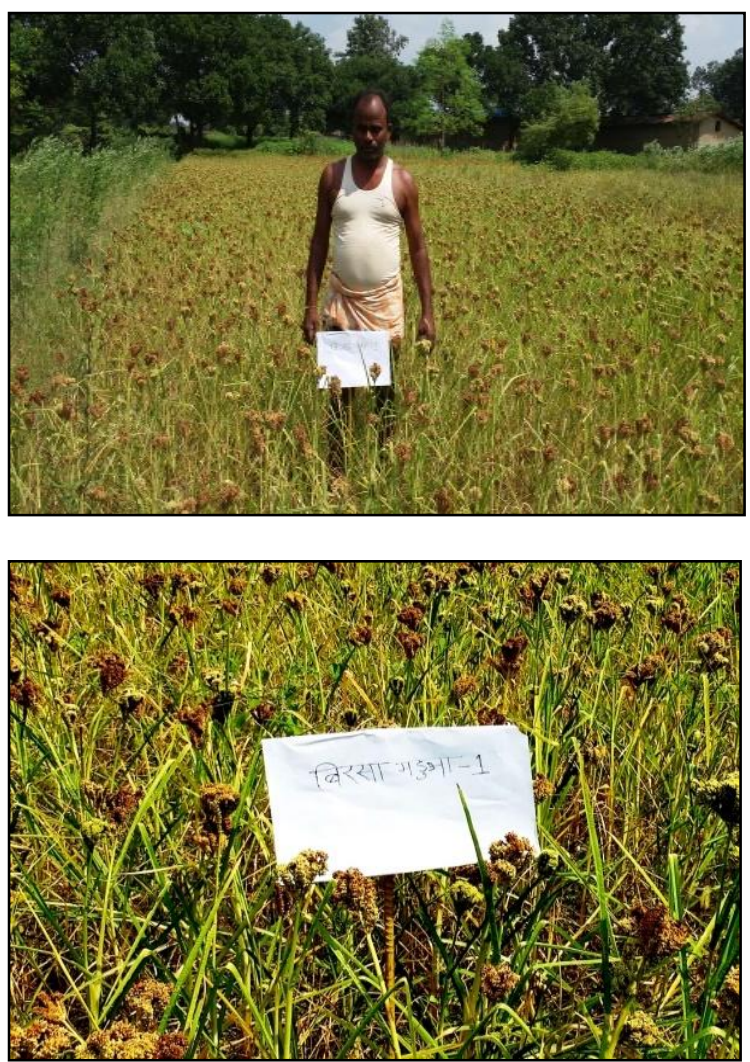

\section{Production potential of ragi}

Birsa Madua-1 variety of ragi crop was grown in upland areas of four villages of Ranchi district during the Kharif season of 2018 (Figure 5). The performance of the ragi variety, Birsa Madua-1 under the seasonal conditions in selected villages is provided in table 3. It showed an average yield of 37.61 quintal ha ${ }^{-1}$ from all the four selected villages and an average net return of $\square 47,103.25$ ha ${ }^{1}$.The cropping period received about 438.6 $\mathrm{mm}$ of rainfall which is $56.8 \%$ less than the normal rainfall of $1091.2 \mathrm{~mm}$ (Table 1). There were also five long-duration dry spells during crop growth period which was the main constraint in the crop's optimal performance. Even with such weather constraints, the average benefit-cost ratio of ragi cultivation in the four selected villages came about 2.28 (Table 3 ).
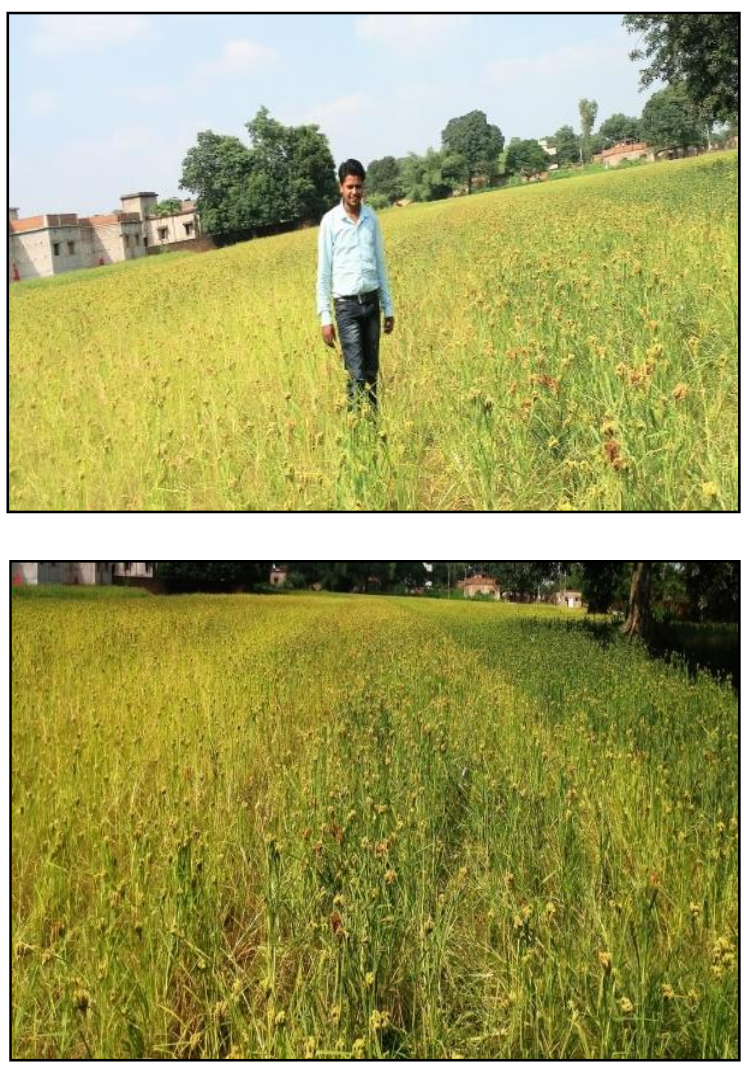

A calendar year can be divided into four major seasons viz: pre-monsoon (March to May), monsoon (June to September), postmonsoon (October to November), and winter (December to February) (Kumar et al., 2009). It is clearly observed from the rainfall pattern that the intensity of rainfall during the monsoon period is decreasing while the postmonsoon rainfall is increasing slowly. The temperature and its fluctuations are also highest in April and May which is clearly visible from the monthly maximum and minimum temperature and monthly diurnal temperature range, respectively. The early Kharif seasons is thus marred with high temperatures and also less rainfall which could have detrimental effects on the production of crops grown during this season. The monthly potential evapotranspiration is also highest in the months of April, May, and June (Figure 4), which corresponds to the 
increase in temperature. The loss of soil water is thus highest during this season, which is also an important factor in the context of Kharif crop production. All these changing conditions have made the farming community think about the contingent or substitution crop which can cope up with the weather aberrations without hampering the economics and sustenance. A proper crop planning has become a key step in the process of farming to mitigate the changing situations. The requirement of weather-based agriculture and their implementation has become a must.

The production study of drought-tolerant ragi variety, Birsa Madua-1, brings forward the fact that it can be used as the substitution crop in the state of Jharkhand. The crop can withstand the erratic rainfall pattern and requires fewer nutrients from the soil to flourish. Eventhough from the physicochemical properties of soil, it is very clear that soil in this region is very much able to fulfil the nutrient requirements of ragi crop. From the economic point of view, ragi is now very much in demand among the consumers which is changing it to a high-value crop and thus it is fetching higher prices to the farmers. As discussed earlier, ragi is very nutritive as it is designated as the model nutraceutical crop and has the production potential near to major cereals. These two characteristics match the statements of fulfilling agricultural demand of the people.

It is concluded that, there is a clear apparent change in rainfall and temperature pattern of Ranchi, Jharkhand which is compelling the agricultural community to come with relevant ideas to cope with it. One of the best solutions is substituting to the cultivation of ragi crop which shows better yield and economic returns under changing conditions. The cultivation of ragi should be encouraged in areas of Jharkhand where such weather alterations are taking place and have a similar agro-ecosystem to that of Ranchi.

\section{References}

Adugna, A., Tesso, T., Degu, E., Tadesse, T., Merga, F., Legesse, W., Tirfessa, A., Kidane, H., Wole, A., andDaba, C. (2011). Genotype by environment interaction and yield stability analysis in finger millet (Eleusine coracana L. Gaertn) in Ethiopia. American Journal of Plant Sciences, 2: 408-415.

Antony, U., Sripriya, G., and Chandra, T. S. (1996). Effect of fermentation on the primary nutrients in finger millet (Eleusine coracana). Journal of Agricultural and Food Chemistry, 44(9), 2616-2618.

Antony, V. (1998). Antinutrient reduction and enhancement in protein, starch and mineral availability in fermented flour of finger millet. Journal of Agricultural Food Chemistry, 46(7): 2578-2582.

Devi, P. B., Vijayabharathi, R., Sathyabama, S., Malleshi, N. G., andPriyadarisini, V. B. (2014). Health benefits of finger millet (Eleusine coracana L.) polyphenols and dietary fibre: a review. Journal of Food Science and Technology, 51(6), 1021-1040.

Gull, A., Jan, R., Nayik, G. A., Prasad, K., and Kumar, P. (2014). Significance of finger millet in nutrition, health and value-added products: a review. Magnesium (mg), 130(32), 120.

Gupta, S. M., Arora, S., Mirza, N., Pande, A., Lata, C., Puranik, S., Kumar, J.,and Kumar, A. (2017). Finger millet: a "certain" crop for an "uncertain" future and a solution to food insecurity and hidden hunger under stressful environments. Frontiers in Plant Science, 8, 643.

Gupta, S., Gupta, S. M., Gupta, A. K., Gaur, V. S., and Kumar, A. (2014). Fluctuation of Dofl/Dof2 expression ratio under the influence of varying nitrogen and light conditions: involvement in differential regulation of 
nitrogen metabolism in two genotypes of finger millet (Eleusinecoracana L.). Gene, 546(2), 327-335.

Kumar, S., Merwade, V., Kam, J., and Thurner, K. (2009). Streamflow trends in Indiana: effects of long term persistence, precipitation and subsurface drains. Journal of Hydrology, 374(1-2), 171-183.

McKeown, N. M., Meigs, J. B., Liu, S., Wilson, P. W., and Jacques, P. F. (2002). Whole-grain intake is favourably associated with metabolic risk factors for type 2 diabetes and cardiovascular disease in the Framingham Offspring Study. The American Journal of Clinical Nutrition, 76(2), 390-398.

Mgonja, M. A., Lenne, J. M., Manyasa, E., and Sreenivasaprasad, S. (2007). "Finger millet blast management in East Africa. Creating opportunities for improving production and utilization of finger millet," in Proceedings of the First International Finger Millet Stakeholder Workshop, Projects R8030 \& R8445 UK Department for International Development-Crop Protection Programme, (Patancheru: International Crops Research Institute for the Semi-AridTropics), 196.
Okalebo, J. R., Jutto, P. M.,andGathera, K. W. (1991). Effect of form and method of phosphate fertilizer application on maize, sorghum and millet growth in semi-arid environment of Kenya. II. Effect of bulrush and finger millet. East African Forestry Journal, 55: 239-248.

Pragya, S., and Singh, R. (2012). Finger millet for food and nutritional security. African Journal of Food Science, 6(4): 77-84.

Seetharam, A., and Krishne Gowda, K. T. (2007). Production and utilization of small millets in India-Food uses of small millets and avenues for further processing and value addition. $P C$, AICSMIP, 1-8.

Shree, S., and Kumar, M. (2018). Analysis of seasonal and annual rainfall trends for Ranchi district, Jharkhand, India. Environmental Earth Sciences, 77(19), 693.

Singh, P., and Raghuvanshi, R. S. (2012). Finger millet for food and nutritional security. African Journal of Food Science, 6(4), 77-84.

Singh, R. P., and Prakash, J. (2017). Transformation of Agriculture in Jharkhand. Agro-Economist, 4(1), 4554.

\section{How to cite this article:}

Nishar Akhtar, Anwesha Dey, Gufran Ahmad, Firoz Ahmad4 and Md. Mahtab Rashid. 2020. Potential and economics of Ragi (Eleusine coracana L. Gaertn.) cultivation under changing weather conditions of Ranchi, Jharkhand. Int.J.Curr.Microbiol.App.Sci. 9(02): 467-476. doi: https://doi.org/10.20546/ijcmas.2020.902.058 